\title{
The influence of thermal load profile of building on the air/water heat pump efficiency simulation
}

\author{
Matgorzata Szulgowska-Zgrzywa ${ }^{1,}$, and Krzysztof Piechurski ${ }^{1}$ \\ ${ }^{1}$ Wroclaw University of Science and Technology, Faculty of Environmental Engineering, \\ Wybrzeże Wyspiańskiego 27, 50-370 Wrocław, Poland
}

\begin{abstract}
In this paper the authors analysed the impact of the calculation method of the partial load conditions and the accuracy of the energy demand profile on the simulation results of the air/water heat pump operation supplying the heating system. All the analyses results were compared to the results acquired for the real installation of the air/water heat pump located in Poland. The authors assessed the inaccuracy of the unit's efficiency estimation resulting from the simplified thermal load profile of the air/water heat pump. It has been showed that using the monthly energy demand as the input data gives satisfactory results. Inaccuracy of the monthly simulation results in relation to simulations carried out on the actual hourly energy demand by no more than $7 \%$ is acceptable. On average, this deterioration did not exceed $3 \%$.
\end{abstract}

\section{Introduction}

The data on the thermal load of the building $\left(Q_{B}\right)$, referred in the article to demand for the heating power of the central heating system, for the simulation of the air/water heat pump energy efficiency can be obtained in several ways. These may be the measurement data, the results of the detailed energy simulations or the results of an easy calculation based on the annual energy demand or the design thermal load. A typical time step for the building energy simulations is monthly or hourly step [1]. The accuracy of the hourly models is high. They take into account the majority of parameters affecting the energy demand for heating of the analyzed building. The accuracy of the monthly models for calculating the energy demand in buildings is slightly lower, but they are widely used. For example, such calculations are mandatory in the process of the energy certification of buildings [2]. In opposition to this, the bin step [3-6] is commonly used to analyze the energy efficiency of the heat pumps. As a result of the fact that heat pump efficiency models are developed in the bin step, not in the time step, there are commonly applied methods that allow approximating the energy demand and the thermal load of the building in the next calculation steps based on a design thermal load or on an annual energy demand for heating. There are two approaches to creating the thermal load profile in the bin step [7].

The first method (further referred to as profile A) is the calculation of the thermal load of the facility based on the relative thermal load coefficient $(\varphi)$ and the design thermal load

\footnotetext{
*Corresponding author: malgorzata.szulgowska@pwr.edu.pl
} 
of the building $\left(Q_{B}{ }^{\text {des }}\right)$. The relative thermal load coefficient is defined as a function of the internal temperature $\left(T_{i n t}\right)$, the ambient temperature $\left(T_{a}\right)$ and the design ambient temperature $\left(T_{a}^{d e s}\right)$, and is described by the formula (1).

$$
\varphi=\frac{T_{i n t}-T_{a}}{T_{i n t}-T_{a}{ }^{d e s}}
$$

The thermal load of the building $\left(Q_{B}\right)$ can be calculated using the transformed formula for describing the relative thermal load coefficient (2).

$$
\varphi=\frac{Q_{B}}{Q_{B}{ }^{d e s}} \Leftrightarrow Q_{B}=Q_{B}^{\text {des }} \cdot \varphi
$$

This formula allows to estimate the building thermal load assuming that it is linearly dependent on the outside air temperature $\left(T_{a}\right)$. The influence of the internal heat gains and the solar heat gains is neglected. In Poland, the above calculations are usually made for the internal air temperature adopted as $T_{i n t}=20^{\circ} \mathrm{C}$. The standard EN 14825 [4] for testing and analyzing the operation of the heat pumps recommends the adoption of this temperature as $T_{\text {int }}=16^{\circ} \mathrm{C}$. In order to determine not only the thermal load, but also the heat energy demand in the building at a given bin step, the knowledge of the climate curve for the analyzed localization is required. The number of the hours of occurrence of a given ambient air temperature $(N h)$ allows to determine the thermal energy demand $\left(\Sigma Q_{B}\right)$ attributable to the given ambient air temperature value (formula (3)). The amount of this energy will generally be overestimated due to the fact that heat gains in the input data are not included.

$$
\Sigma Q_{B}=Q_{B} \cdot N h
$$

The second method (further referred to as profile B), also uses the climate curve, but it is characterized by the reverse approach, i.e. the input value is the annual energy demand $\left(\Sigma Q_{B}{ }^{t o t}\right)$, not the design thermal load $\left(Q_{B}{ }^{\text {des }}\right)$. This method is described in EN 15316-4-2 [3] and it allows to estimate the thermal load required by the building, taking into account the internal and solar heat gains, using the formulas described below. The degree-hours for the given ambient temperature $(D h)$ are calculated on the basis of the equation (4).

$$
D h=\left(T_{i n t}-T_{a}\right) \cdot N h
$$

This value give the possibility to calculate the relative thermal energy demand coefficient $\left(\varphi_{D h}\right)$ according to equation (5).

$$
\varphi_{D h}=\frac{D h}{\sum D h}
$$

The relative thermal energy demand coefficient can be used to calculate the energy demand for heating in a given bin step (6).

$$
\Sigma Q_{B}=\Sigma Q_{B}{ }^{t o t} \cdot \varphi_{D h}
$$

The conversion from the value of the heat energy demand to the thermal load value is made by distributing it evenly to each hour of the bin step, as described in equation (7).

$$
Q_{B}=\frac{\Sigma Q_{B}}{N h}
$$

A comparison of the thermal load value and the heat energy demand depending on the ambient air temperature value for an exemplary building using the profile A and the profile $\mathrm{B}$ is shown in Fig. 1. 
The discrepancies between the calculation results based on the particular method are significant. It should be noted that they will be larger the greater the share of the heat gains in the total energy demand in the facility is, as shown in Fig. 2 [7].
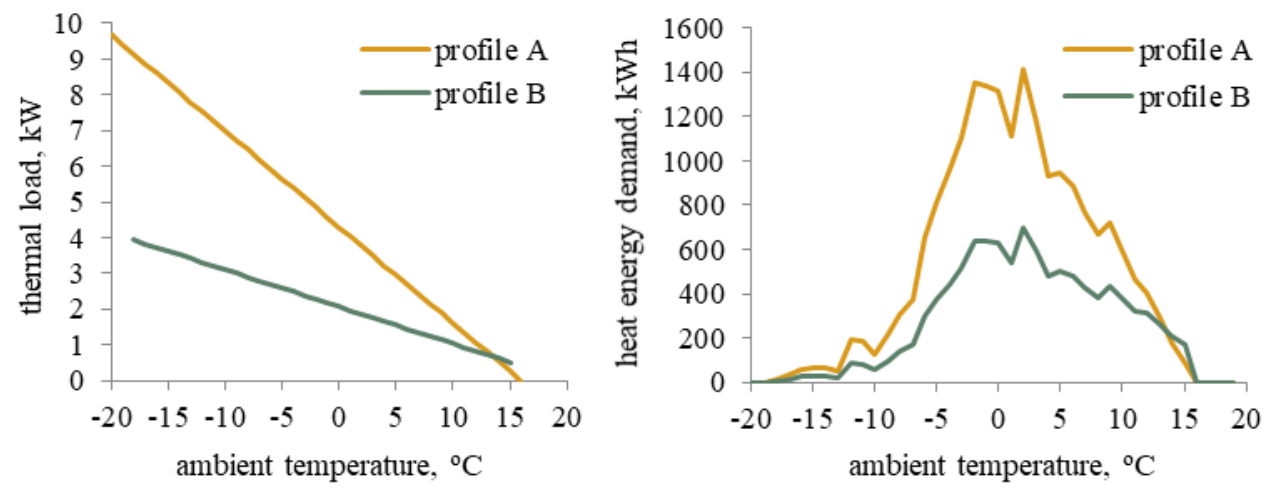

Fig. 1. The examples of the thermal load profiles of a building: profile A [16] and profile B [17].

The divergence between the profiles A and B will be greater when the building is better insulated and designed to maximize the passive heat gains. The air/water heat pumps are dedicated as the heat energy sources to the low-energy buildings with a high level of the thermal insulation, the low ventilation losses and designed for the maximum use of solar heat gains. It should be taken into account that the most heat pump systems will be in the group with the highest discrepancies in the calculation results using this two simplified models to determine the heat demand profile. The energy demand profile developed with their application may significantly differ from reality. Even if the B profile is used, the even distribution of the solar heat gains for the subsequent temperatures in the year is not precise because the share of these heat gains in the energy balance of the facility in subsequent periods of the year is varying [7].

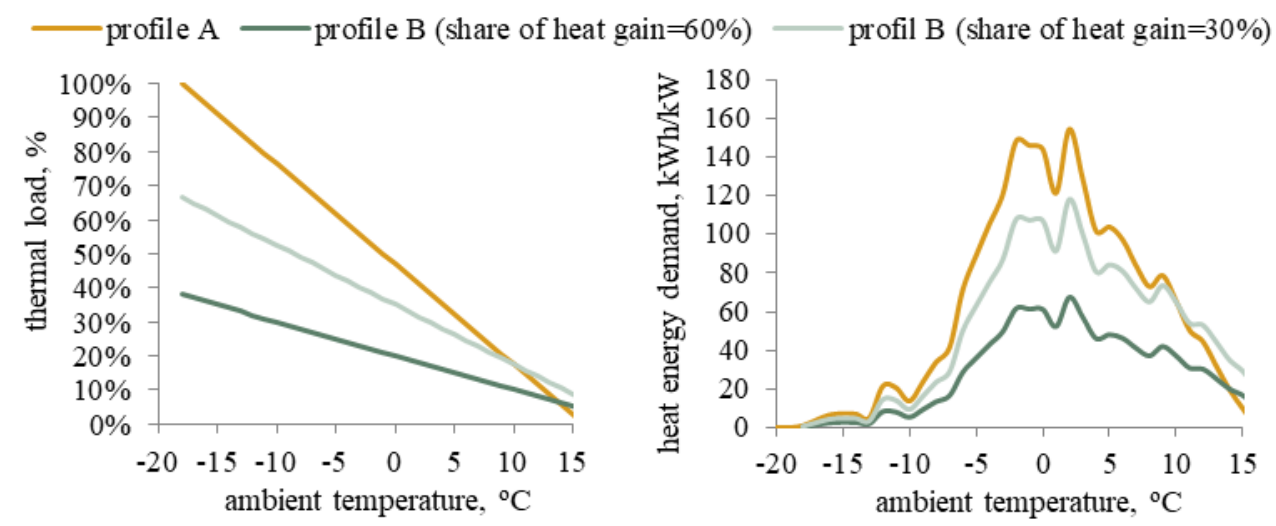

Fig. 2. The thermal load profiles depending on the share of the solar heat gains in the energy balance of the building [7].

This article analyzes the influence of mapping accuracy of the thermal load profile on the results of the heat pump's energy efficiency simulation. Point 2.1. shows how the simulation results can differ when using the EN 14825 [4] and EN 15316 [3] guidelines. In the further part of the article (points 2.2 and 2.3), the simplification of this profile is verified to preserve the good accuracy of the simulation results of the air/water heat pump energy efficiency in monthly and hourly steps. 


\section{The thermal load profile of the building and the results of the air/water heat pump operation simulation}

\subsection{Description of the research problem}

The described calculation approaches represents two alternative ways of obtaining input data for modeling the operation of an air/water heat pump in the temperature step. The results of the heat pump sizing and analysis based on the use of each of these models will give significantly different results [8]. This is the result of both determination of completely different bivalent points, different areas of mismatch between the heat pump's power and the heating demand of the building, as well as different partial load factors in the area of on/off regulation. This issue is illustrated in Fig. 3, which shows the situation when the heat pump was sized for the heating demand on the building resulting from profile $\mathrm{A}$. The bivalent point is $T_{a}^{b i v}=-10^{\circ} \mathrm{C}$. This should be considered relatively correct for climatic conditions in Poland. In relation to the heating load resulting from the profile B, the heat pump is significantly oversized, the bivalent point is absent. In the case of simulation for profile A there is a small area of the auxiliary heat source operation. For the profile $\mathrm{B}$ analysis, this area does not occur. The area of operation with partial load appears for profile A above the ambient temperature of $-2^{\circ} \mathrm{C}$. In the case of profile $\mathrm{B}$, the partial load area occurs at all points of the ambient temperature [7].

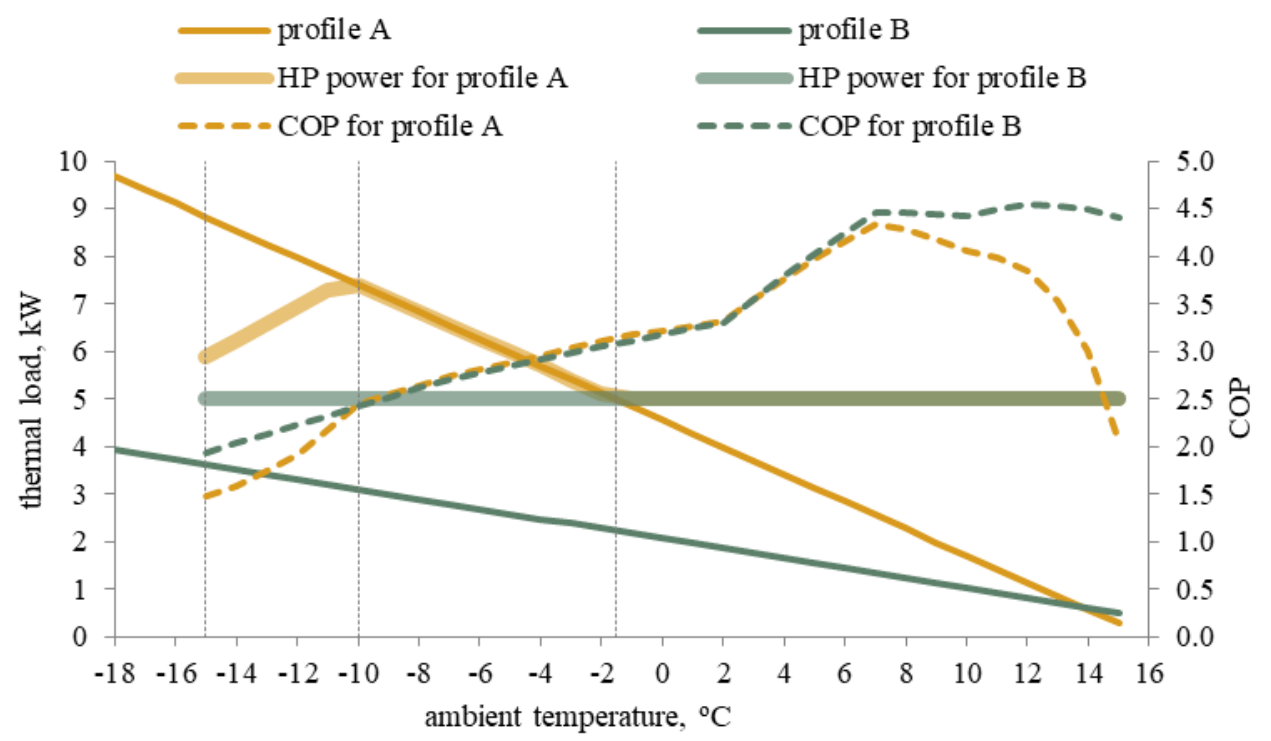

Fig. 3. Operational parameters of the air/water heat pump depending on the thermal load profile of the building [7]. 
The results of the calculations carried out with both methods for an exemplary object are summarized in Table. The SCOP values differ by around $5 \%$, which can be considered as an acceptable level. However, the determined values of heat and electricity demand differ by approximately $50 \%$. A detailed discussion of this issue is carried out in [8], which shows that none of these models is fully reliable. In summary, it is difficult to accept guidelines that actually describe the same calculation problem, but are based on data that significantly differs from each other, which results in equally divergent results.

Table 1. The heat pump's energy efficiency calculation results according to standards [3] and [4].

\begin{tabular}{|c|c|c|c|}
\hline Parameter & Profile A [3] & Profile B [4] & $\begin{array}{c}\text { Difference: } \\
\text { (B-A)/A }\end{array}$ \\
\hline Heating energy demand & $21041 \mathrm{kWh} /$ year & $10479 \mathrm{kWh} /$ year & $-50 \%$ \\
\hline Electrical energy demand & $6479 \mathrm{kWh} /$ year & $3067 \mathrm{kWh} /$ year & $-52 \%$ \\
\hline SCOP & 3.25 & 3.42 & $+5 \%$ \\
\hline
\end{tabular}

\subsection{Simulation analysis methods}

In this part of the article, the impact of the accuracy of the building's heating demand profile on the results of the energy efficiency simulation of the air/water heat pump has been analyzed. The analysis of this problem was made by comparing the results of simulations carried out on the actual thermal load data and on the models. Features of simulations carried out are described below:

- simulation 1 - calculations in an hourly step; partial load analysis method recommended by EN 14825; reduction factor $C c=0.8$; analysis on the actual (measured) thermal load profile;

- simulation 1(A) - calculations in an hourly step; partial load analysis method

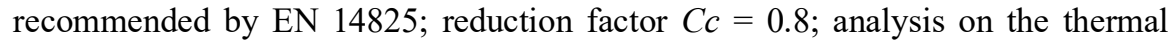
load profile A;

- simulation 2 - calculations in an hourly step; partial load analysis method recommended by EN 15316; power consumed by the heat pump in stand-by mode $Q_{e l, s-b y}=91 \mathrm{~W}$; analysis on the actual (measured) thermal load profile;

- simulation 2(B) - calculations in an hourly step; partial load analysis method recommended by EN 15316; power consumed by the heat pump in stand-by mode $Q_{e l, s-b y}=91 \mathrm{~W}$; analysis on the thermal load profile B - thermal load is profiled on the basis of heating energy demand in particular months (resulting from measurements);

- simulation 3 - calculations in an hourly step; partial load analysis method described in the article [9]; reduction factor $a=0.28$; analysis on the actual (measured) thermal load profile;

- simulation 3(B) - calculations in an hourly step; partial load analysis method described in the article [9]; reduction factor $a=0.28$; analysis on the thermal load profile B - thermal load is profiled on the basis of heating energy demand in particular months (resulting from measurements).

In the case of 2(B) and 3(B) simulations, the thermal load profile of the building is based on monthly values resulting from the measurements. Values of characteristic parameters for the models describing the heat pump's operation at partial load conditions $\left(C c, Q_{e l, s-b y}, a\right)$ were also determined on the basis of measurement data. Details are described in articles $[9,10]$. 


\subsection{Results and discussion}

All of the analyzes performed are based on actual ambient air temperature values and actual outlet water temperature of the heating system. Only the value of the thermal load of the building (profile A or B) and the way of modeling the impact of operation at partial load conditions were changed. The results of analyzes for models described in chapter 2.2 and measurements of the actual heat pump system are presented in Table.

Table 2. Comparison of simulation and measurement efficiencies of air/water heat pump.

\begin{tabular}{|c|c|c|c|c|c|c|c|c|c|c|}
\hline \multirow{3}{*}{$\begin{array}{l}\text { ज्ञ } \\
\text { ¿ }\end{array}$} & \multicolumn{5}{|c|}{ Real profile of the energy demand } & \multicolumn{2}{|c|}{ Profile A } & \multicolumn{3}{|c|}{ Profile B } \\
\hline & $\mathrm{Q}_{\text {в }}$ & $\begin{array}{l}\text { measur. } \\
\text { SCOP }\end{array}$ & $\begin{array}{l}\text { sim. } 1 \\
\text { SCOP }\end{array}$ & $\begin{array}{l}\text { sim. } 2 \\
\text { SCOP }\end{array}$ & $\begin{array}{l}\text { sim. } 3 \\
\text { SCOP }\end{array}$ & Qв & $\begin{array}{l}\text { sim. } \\
1(\mathrm{~A}) \\
\text { SCOP }\end{array}$ & $\mathrm{Q}_{\text {в }}$ & $\begin{array}{l}\text { sim. } \\
\text { 2(B) } \\
\text { SCOP }\end{array}$ & $\begin{array}{c}\text { sim. } \\
3(\mathrm{~B}) \\
\mathrm{SCOP}\end{array}$ \\
\hline & $\mathrm{kWh}$ & - & - & - & - & $\mathrm{kWh}$ & - & $\mathrm{kWh}$ & - & - \\
\hline IX & 772 & 3.77 & 3.56 & 4.05 & 3.79 & 634 & 3.32 & 772 & 4.24 & 3.74 \\
\hline $\mathrm{X}$ & 715 & 3.92 & 3.77 & 4.08 & 3.85 & 559 & 3.56 & 715 & 4.30 & 3.95 \\
\hline $\mathrm{XI}$ & 2699 & 4.10 & 3.93 & 3.98 & 3.93 & 1897 & 3.75 & 2699 & 4.17 & 4.11 \\
\hline XII & 2004 & 3.88 & 3.70 & 3.79 & 3.69 & 1725 & 3.59 & 2004 & 3.80 & 3.72 \\
\hline $\mathrm{I}$ & 3071 & 3.07 & 3.26 & 3.31 & 3.25 & 2791 & 3.20 & 3071 & 3.36 & 3.31 \\
\hline II & 1504 & 3.53 & 3.53 & 3.81 & 3.52 & 1829 & 3.77 & 1504 & 3.88 & 3.54 \\
\hline III & 772 & 3.13 & 2.94 & 3.50 & 3.02 & 1416 & 3.70 & 772 & 3.56 & 3.03 \\
\hline IV & 366 & 2.48 & 2.30 & 3.01 & 2.61 & 962 & 3.79 & 366 & 3.10 & 2.61 \\
\hline $\mathrm{V}$ & 381 & 3.00 & 2.73 & 3.42 & 3.07 & 725 & 3.59 & 381 & 3.36 & 2.86 \\
\hline$\underset{\varpi}{\varpi \varpi}$ & 12284 & 3.50 & 3.44 & 3.67 & 3.50 & 12539 & 3.55 & 12284 & 3.75 & 3.55 \\
\hline
\end{tabular}

In order to assess the effect of the thermal load profile on the simulation results, the accuracy of the simulations performed on the basis of the A and B profiles were compared to the real profile of the energy demand (Tab. 2). A comparison of the errors of the monthly $S C O P$ values, calculated as the difference between measured and simulated SCOP in relation to the measured SCOP, is shown in Fig. 4.

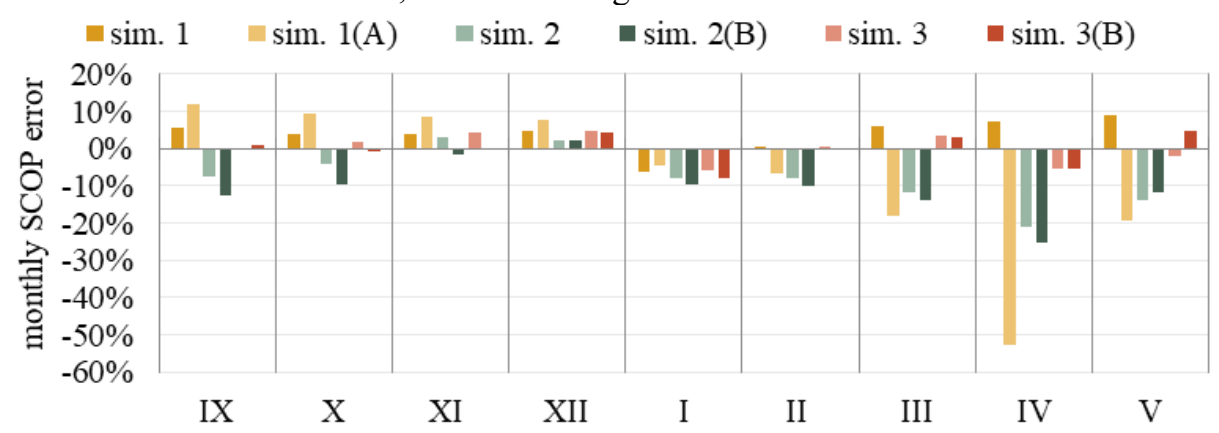

Fig. 4. Comparison of monthly $S C O P$ errors between modelling, actual and theoretical thermal load profiles.

Between simulations 1 and 1(A), the difference in the monthly error rate is very high, especially for warmer months, and reaches over 60\% in April. For simulations 2 and 2(B) the differences are much smaller. An increase of errors by no more than $7 \%$ using such a significant simplification in modeling the thermal load is acceptable. Such results lead to the conclusion that energy simulations of heat pump's operation based on a thermal load model in which the input value is a monthly rather than an annual energy demand, give satisfactory results. In addition, it is worth noting that the best results are obtained for simulations 3 and 3(B). This is the result of the applied method of estimating the effect of 
the device operation at partial load. Simulation 2(B), which is based on the same thermal load profile, give satisfactory results only in colder months. This proves that a precise determination of the $C O P$ reduction during operation at partial load conditions is crucial for obtaining correct results.

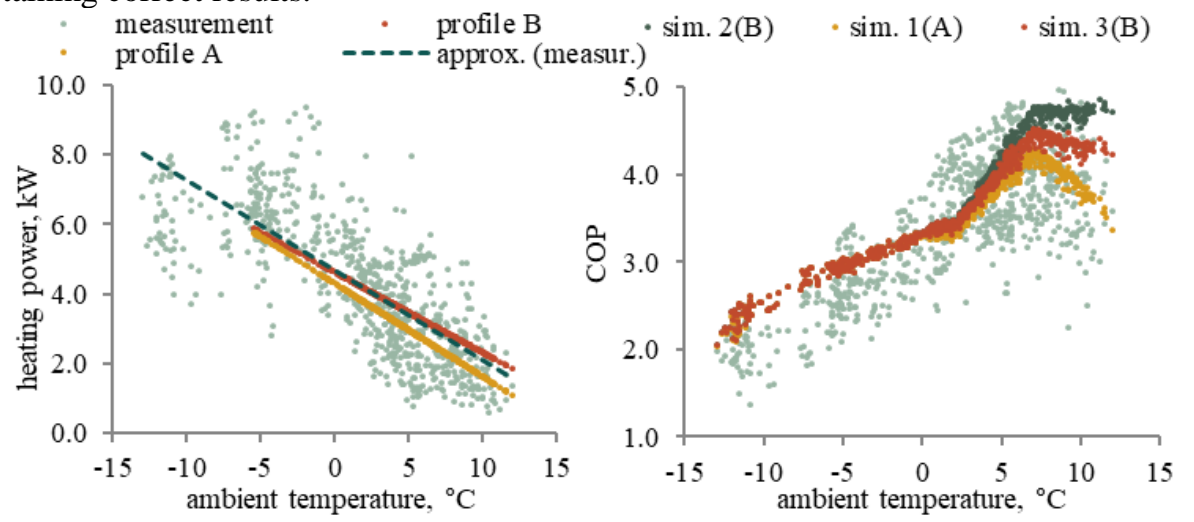

Fig. 5. Thermal load of the building and hourly $C O P$ values from calculations in simulation 1(A), 2(B) and 3(B) relative to the measurements for January.

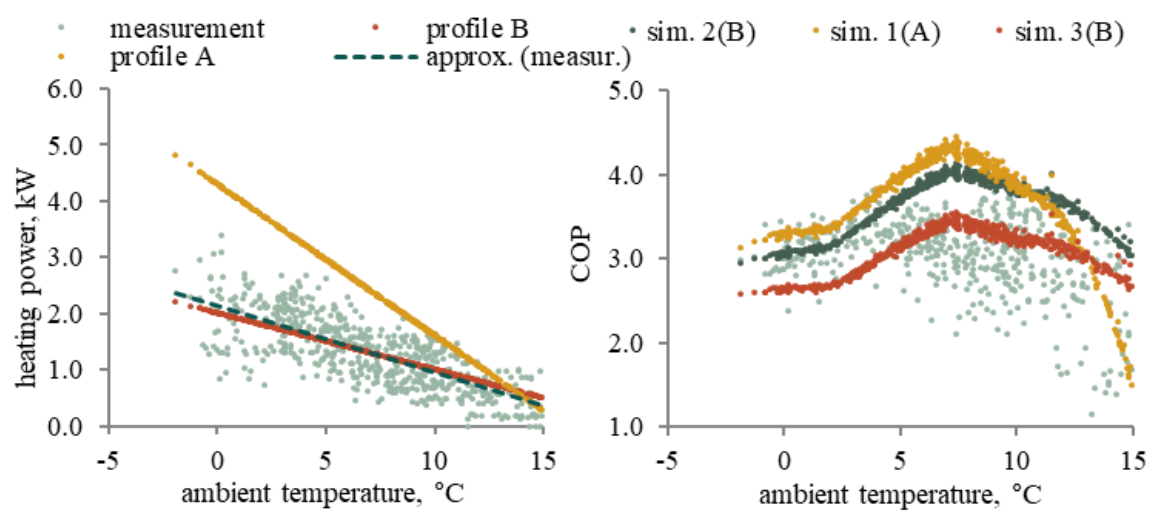

Fig. 6. Thermal load of the building and hourly $C O P$ values from calculations in simulation $1(\mathrm{~A})$, 2(B) and 3(B) relative to the measurements for March.

Fig. 5 and Fig. 6 show the hourly $C O P$ values and the thermal load of the building obtained from simulations 1(A), 2(B) and 3(B) in combination with the measurement data. The plots show differences in the application of the profile $\mathrm{A}$ in simulation 1(A), taking into account one (annual) thermal load profile, and profile B in simulations 2(B) and 3(B), including profiles calculated separately for each month. Profile A does not give the possibility to reflect the actual thermal load of the building, which can be stated by comparing the results in both figures. The deviation of the profile A from the trend line for the measurement data in January is small, which results in relatively correct $C O P$ values. In March, the deviation is significant, which results in incorrections in the calculated COP values. The correct values of the thermal load of the profile B in both cases were obtained by developing it individually for each month. Despite this, the $C O P$ values obtained in simulation 2(B) are not entirely satisfactory. The reason is the method used to calculate the impact of operating at partial load on the energy efficiency of a heat pump. In the case of simulation 3(B), the results improved significantly. The average error in calculating the monthly values of SCOP is $-0.2 \%$, with the highest of $-8.1 \%$ for January (see Fig. 4). 


\section{Conclusions}

The article presents the influence of the thermal load profile of the building on the results of the simulations of the air/water heat pump operation. The calculations were made also for various methods of modeling the impact of operating at partial load. It was found that the dependence between adjusting the thermal load profile of the building to reality and the accuracy of the monthly SCOP and hourly COP simulations of the heat pump is evident. At the same ambient air temperature, the differences in the heating demand due to the heat gain in the total energy balance of the building are significant. They result in different values of the calculated partial load ratio, thus the disagreements in the hourly $C O P$ calculations. It is worth noting that by using the monthly heat energy demand for the building, it is possible to obtain more accurate results of hourly COP and SCOP of the installation. This in turn leads to a precise determination of the monthly electricity demand for the air/water heat pump system. The inaccuracies of the monthly simulation results in relation to the simulations carried out on the actual hourly energy demand by no more than $7 \%$, while simplifying the modelling so significantly, are acceptable. On average, the errors did not exceed $3 \%$.

\section{References}

1. EN ISO 52016-1:2017-09, Energy performance of buildings - Energy needs for heating and cooling, internal temperatures and sensible and latent heat loads - Part 1: Calculation procedures

2. Rozporządzenie Ministra Infrastruktury i Rozwoju z dnia 3 czerwca 2014 r. w sprawie metodologii obliczania charakterystyki energetycznej budynku i lokalu mieszkalnego lub części budynku stanowiącej samodzielną całość techniczno-użytkową oraz sposobu sporządzania i wzorów świadectw charakterystyki energetycznej

3. EN 15316 Heating systems in buildings - Method for calculation of system energy requirements and system efficiencies - Parts 3-1, 3-2 and 4-2

4. EN 14825:2016-08, Air conditioners, liquid chilling packages and heat pumps, with electrically driven compressors, for space heating and cooling - Testing and rating at part load conditions and calculation of seasonal performance

5. C. Naldi, G. L. Morini, E. Zanchini, Sustainable Cities and Society 12, 85-91 (2014)

6. M. Dongellini, C. Naldi, G. L. Morini, Applied Thermal Engineering 90, 1072-1081 (2015)

7. M. Szulgowska-Zgrzywa, Monthly energy efficiency of air/water heat pump systems (Oficyna Wydawnicza Politechniki Wrocławskiej, 2019, Prace Naukowe Wydziału Inżynierii Środowiska Politechniki Wrocławskiej, 2019)

8. K. Piechurski, Porównanie efektywności eksploatacyjnej pompy ciepta powietrze/woda $z$ wynikami symulacji uzyskanych za pomoca wybranych metod analitycznych (praca magisterska, 2016)

9. K. Piechurski, M. Szulgowska-Zgrzywa, J. Danielewicz, E3S Web of Conferences 44, 00139 (2018)

10. K. Piechurski, M. Szulgowska-Zgrzywa, J. Danielewicz, E3S Web of Conferences 17, 00072 (2017) 